\title{
Case studies of Kenyan digital villages with a focus on women and girls
}

\author{
David Hallberg, Mildred Kulecho, Ann Kulecho, Loreen Okoth
}

\begin{abstract}
The present article refers to a case study on the Kenyan Government's Digital Villages Project (DVP). The Kenyan Government, together with external stakeholders and private contractors, is increasing their ICT investments to provide the entire population with information and communication regardless of demographic factors. In the Kenyan context, digital villages are what normally other countries refer to as telecentres, i.e. a centre that provides services with regard to Internet and telecommunication. In this case, the digital villages also offer education, learning, and e-Government. The present study wants to learn whether DVP is accessible, and appropriate to women and girls in resource-poor environments and, thus, successful. The following questions guided the study: 1. Who are the users of Pasha Centres? 2. How and for what purposes are Pasha Centres used? 3. In what way do Pasha Centres consider local needs (e.g. education, literacy, job, and diversity)? 4. What do users and managers do to encourage female users? The study is built upon observations and interviews. The results show that male users generally believe that women have a lack of knowledge and understanding of ICT. The results also show that what is said by the government is not fully implemented at the local levels. The authors believe, despite this, that DVP has the potential to serve the population in vulnerable areas and that the government should continue focusing on similar projects.
\end{abstract}

Keywords: digital village, gender, ICT-service, Kenya, lifelong learning, resource-poor environment

\section{Introduction}

The Kenyan government, together with external stakeholders and private contractors, is increasing its ICT investments in order to reach the entire population regardless of demographic factors, whereas the Digital Villages Project $(D V P)$ is one of the largest efforts. Digital villages are referred to as Pasha Centres, meaning "to inform", and are located in rural and resource-poor environments. In the Kenyan context, digital villages are what normally other countries, e.g. in Sri Lanka and India, refer to as telecentres (e.g. Hansson et al, 2010). A telecentre in Kenya however, normally refers to what Jensen and Esterhuysen (2001) defines as micro and mini telecentres. Therefore, a digital village in Kenya has a similar role as a telecentre in many other countries, i.e. to provide services with regard to Internet and telecommunication. In addition, digital villages are also meant to provide certain training, education, and governmental services (e-Government). In this respect, it is a challenge for the Kenyan Government to meet the needs of a population, which are diverse in terms of demography and sociocultural background.. Summaries of Pasha Centres are available on the Kenyan Government's website (http://www.pasha.co.ke). There are several reasons to initiate the DVP as noted by the Kenya ICT Board (2010): 
"[T] he ICT sector is currently more active in urban areas, resulting in wide regional disparities in the distribution of ICT facilities. In order to address this disparity, the Kenya ICT Board (KICTB) is supporting the roll out of new "electronic centres" which shall be named Pasha Centres (and are also commonly referred to as Digital Villages). Existing e-centres may also be upgraded. Pasha Centres are hubs that provide a host of services to the public via computers connected to the internet, or by using and marketing other ICT-enabled applications. A core requirement for this project is to set up and manage a Digital Village Revolving Fund (DVRF) that will advance loans to entrepreneurs to enable them establish the PASHA centres. In addition, the Kenya ICT Board will also provide technical support to the successful PASHA entrepreneurs. Other components of this initiative include training."

Further, the ICT Board Kenya (2010b) stresses the following:

"Kenya ICT Board will ensure that the people living around the digital villages fully understand how and why they should take advantage of the services available. In this way, the Digital villages will thus become a relevant and essential part of their daily lives, adding value and creating opportunities. It is expected that this will result in wealth creation, employment, and poverty reduction."

Indeed, the government strives to recognise people's everyday lives in this effort and creates better conditions of living. These thoughts are in line with the philosophy of lifelong learning (ebrary, 2003; European Commission, 2007; Fontelles \& Enestam, 2006; UNESCO, 2009).

For the Digital Villages Project to be successful it is important to take into account the everyday lives of women and girls. Though it has become commonplace to take advantage of ICTs to enable the remote populations to enjoy the benefits of commerce, education, and health services (Lallement et al, 2006), women and girls are at risk of falling behind when it comes to ICT, especially within the context of emerging economies. (Huyer, 2003). Further, women in rural areas are more vulnerable compared to those in urban areas (Project Africa, 2010). This is not only a problem of morality and equality. Women are significant actors in the socio-economic development of any nation (Dlodlo, 2009). To this end, ways of enhancing female's access to ICT in rural areas include: women sharing ICT experiences, facilitating ICT access for women, creating an enabling environment for ICT in education, and increasing ICT careers for women.(Dlodlo, 2009). The same source also stresses the importance of general collaboration on ICT activities to pursue common ICT objectives.

The present article exhibits a study of four Pasha Centres. The overall purpose is to learn whether DVP is accessible, and appropriate to women and girls in resource-poor environments and, thus, successful in supporting their everyday lives. The following questions guided the study:

1. Who are the users of Pasha Centres?

2. What do users and managers do to encourage female users?

3. How and for what purposes are Pasha Centres used?

4. In what way do Pasha Centres factor in local needs (e.g. education, literacy, job, and diversity)? 


\section{Review of telecentres}

For the review Libris, Science Direct, ERIC, and Google Scholar were employed to retrieve articles on "digital village*" and "telecent*". As a complement, common Internet browsers were also employed to broaden the review.

"One strategy for bridging the digital divide within a nation, and between nations, is to encourage telecenters". (Rogers \& Shukla, 2001) The first telecentres were established in the early 1980s in Scandinavia to promote the use of advanced Information and Communications Technology (ICT). They were funded from public funds for three years.. This approach was seen as a way of letting people, especially farmers, experiment with different ICTs. Similar projects were subsequently replicated in other parts of Europe and North America. The centres aimed mainly at facilitating access to computers and online applications., African countries such as Ghana, Kenya, and Senegal were early in establishing private telecentres. Nonetheless, apart from private contractors, telecentres in Africa have received considerable support from international development organisations, e.g. UNESCO, ITU and IDRC (Benjamin, 2000; Jensen \& Esterhuysen, 2001).

Ndeta (2003) states that there is little literature on the use of ICT in Kenya. The government of Kenya and its partners launched a poverty eradication strategy where the role of ICT was considered as minimal in poverty eradication. However, in the Kenya's Poverty Reduction Strategy Paper for the period 2001-2003, the government recognises that telecommunication, information services, and IT sectors are important for economic growth. The reasons for lack of ICT-services in Kenya are bureaucracy, lack of professionalism in the business sector, corruption, illiteracy, and poverty. She further observes that "this little-used service" may die before it grows unless more effort is put in to make it accessible to the people of Kenya (Ndeta, 2003: 94). This has meant that the Internet is a secondary need especially to rural elites since they first need to learn how to handle a computer before using it. In addition, the cost is high for average users. This does not apply to the educated Kenyans who have a good salary. Furthermore, Ndeta stresses, the Kenyan government intends to strengthen its IT capacity and improve service delivery for all by working with entrepreneurs to drive down prices by increasing competition. As a result, the government proposed the provision of digital villages. A drawback with Ndeta's study is that it largely relies on other empirical findings without major critical considerations. This could be a reason why ending the article in quite obsolete words, namely "Kenyans are a humble and curious society and have found the Internet fun." (Ndeta 2003, p. 99). Another work found is a manual on community telecentre that includes the definition of digital villages. The manual states, telecentres owned by the communities themselves address the needs of people in Africa better. Telecentres may be used to provide access to distance education and job activities, access to telephones, e-mail, and other information services.

On Science Direct there are a few articles relating to the topic of this article. Abbott and Yoong (2005) draw from a case study on stages of telecentre development in New Zealand. In their article, telecentres mainly provide employees the opportunity to work within a fully equipped office-like environment without travelling to a business district. They can also be used for community and development purposes if made fully accessible to the general public. 
Most articles on "telecent*" that were found on ERIC are from earlier than 2001 and bring up telecentres in relation to learning; for instance, how telecentres can enable distance education on local level (Larson \& Murray 2008; Ramos et al, 2007). Crellin (1994) article on the Australian telecentre programme, which has a business approach, notes, telecottages (i.e. telecentres) originated in Scandinavia during the 1980s. They were meant to break up the isolation perceived in rural communities, providing easy access to electronic information sources. These cottages brought light to new ideas how to make business, in the agriculture sector, for instance. Differently from most articles, Crellin emphasises, telecentres might be useful for teleconferencing or even videoconferencing. Crellin's article is also fruitful to understand the slow process of connecting different communities using ICT.

Gaiani et al (2009) scrutinises critical issues for successful telecentres in Sri Lanka and India. The objectives of the telecentres studied are to provide useful information to people in rural areas, e.g. public information. Notable aspects on these telecentres are they are managed with non-profit and intended to provide information to the rural villagers for free. Gaiani's study had also a gender focus and comments, "Women experienced barriers to accessing information. Above all, local families were reluctant to let female members join the activities." Based on the empirical data, Gaiani et al (2009) regard the following as imperative for the success of telecentres: ownership, sustainability, languages, education, inclusion, and vision/strategy.

Terry and Gomez (2010) provide a qualitative study of benefits of ICT and barriers facing women to gain fully from ICT hubs. Their data show (figure 1) what kinds of benefits there are for women in using telecentres and what might stop them from gaining fully.

\begin{tabular}{|c|c|c|}
\hline \multicolumn{2}{|c|}{ Benefits of ICT for women } & $\begin{array}{l}\text { Barriers to fully realize } \\
\text { benefits }\end{array}$ \\
\hline Individual Benefits & Collective Benefits & $\begin{array}{l}\text { (barriers affect all, } \\
\text { but especially women) }\end{array}$ \\
\hline $\begin{array}{l}\text { - Empowerment } \\
\text { - Increased } \\
\text { self-esteem } \\
\text { - Reduced isolation } \\
\text { - Access to markets } \\
\text { - Access to health } \\
\text { information }\end{array}$ & $\begin{array}{l}\text { - Economic growth } \\
\text { - Improved } \\
\text { health } \\
\text { - Improved education } \\
\text { - Capacity building } \\
\text { - Cultural transformation }\end{array}$ & $\begin{array}{l}\text { - Location, infrastructure and } \\
\text { connectivity } \\
\text { - Time and money } \\
\text { - Lack of relevant content } \\
\text { - Low education and literacy } \\
\text { - Social norms and perceptions }\end{array}$ \\
\hline
\end{tabular}

Figure 1. Benefits and Barriers of Public Access ICT for Women (Terry \& Gomez, 2010)

Gómez Díaz and Sandoval-Almazán's (2009) deal with organisational learning centres initiated by the Mexican government under the name of e-México. This initiative of providing more citizens with ICT began around 2001. One goal of the project was to change the country by availing basic services such as education, health, and business opportunities in order to bridge the gap between urban and rural communities.

Though Ndeta (2003) reveals remarkable information with regard to the Kenyan context and the Government's ICT initiative, there is a gap in research when it comes to how ICT services take account of women in resource-poor environments. Statistics show high illiteracy rate among African women (Oyedemi 2003, p. 11) and women have often been disregarded when it comes to ICT. 


\section{Methods and materials}

All empirical data were collected between $20^{\text {th }}$ March 2010 and $23^{\text {rd }}$ September 2010. In order to gather background information on the DVP, visits, interviews, and mail conversation were performed with directors of The National Environment Management Authority (NEMA), Institute of Computer Science and Information Technology (ICSIT), Jomo Kenyatta University, and the Government's division for ICT issues (Kenya ICT Board). Questions put to these authorities were all unstructured and open-ended. Besides, information through documentation concerning the Kenyan Government's e-initiatives was gathered. Field studies around four Pasha Centres were carried out and the data collectedSelecting Pasha Centres

In selecting Pasha Centres in different provinces, special attention was given to accessibility in terms of location, i.e. being located in different kinds of environments and provinces. It was also important to establish whether or not the centres were operational. A further consideration was gender, i.e. the number of centres manned by women.

\section{Interviews}

Individual interviews were performed with four government representatives ( 3 male), one university director from a public university (male), five local managers/owners ( 3 male) of Pasha Centres, and nine users ( 3 male). Questions put to government representatives were all openended and unstructured and conducted in two steps. First interviews were performed to learn more about the context and to design further questions. Secondly, interviews were performed as follow-up to fill any gaps. Questions put to other informants were semi-structured and openended (see appendix). All interviewees in the study could choose the language they wanted to use (which turned out to be English and Swahili). Interviews were recorded hence there is a possibility to identify mistakes the interviewers might have made.. Questions were designed to bring out peoples knowledge, experiences, and personal feelings on Pasha Centres. The questions were also designed to gain current status, strategies, and planning horizons of Pasha Centres. Questions were grounded in findings from the literature review (e.g. Gaiani et al 2009).

\section{Observations}

According to Bernard (2000), participant observation means observing from either inside or outside, recording aspects of life around the phenomena. Participant observation was a suitable data collection technique to complement the interviews. The collected and recorded data was transcribed verbatim. The interviewees were observed in the natural environment; hence, it was possible to uncover sensitive activities (Baker, 2006). Interviewers were aware of the effect researchers have on interviewees that might have affected the answers received (Pripp, 1999). The main advantage with observing was that facts difficult to reveal from putting questions could be uncovered. Examples of such facts are the distribution between female and male users and main activities among users.

\section{Analysis}

The analysis started by reading and re-reading the transcripts to become familiar with data (Brammer, 2006). Dey's (1993, p. 68; 71) devices were employed to find a focus. For example, 
Dey proposes consideration on what kind of data is to be analysed, how data can be characterised, why selecting the data, and what personal experience may contribute. The software application MAXQDA 10 for qualitative data analysis was employed. Out of 1067 unique words in the interviews, 73 key words were identified based on their frequency and relevancy to the purpose of the study. These words were then grouped under nine items (demography, knowledge, empower, work, social [culture], personal, ownership, language, economy). The items gave some clues on what interviewees focused on.

\section{Empirical findings}

\section{Interviews with government representatives}

A director at the Institute of Computer Science and Information Technology (ICSIT) Department of Jomo Kenyatta University of Agriculture and Technology mentions that the Government of Kenya through the " $30 \%$ Presidential Directive on Affirmative Action on recruitments, promotions and appointments in the public service" spearheaded by the ministry of gender and other line ministries, intends Kenyan Government to increase the percentage of women employed in ICT sectors to a minimum of thirty per cent. This recognizes however that this remains a challenge and, thus, is difficult to achieve. In order to achieve this among other issues, the Government of Kenya developed the ICT in 2009, which among other things includes the Digital Villages Project.

According to the ICSIT, the Kenya ICT Board is the primary institution responsible for the management of digital villages and digital inclusion initiatives. Further, private contractors supported under Kenya ICT Board for a certain period, which provides certified training program to run digital villages will manage the digital villages.

Kenya ICT Board counts on three Pasha Models for their Pasha Centres, which was inspired by the Capability Maturity Model (CMM) (for further information about CMM, refer to Paulk et al 1993). Basic model offers e.g. basic office services, Internet surfing, and e-mailing. Standard model also offers e.g. basic skills courses, it face to face support, access to government services. Advanced model also offers e.g. remote technical support, wireless access to satellite places, educational and vocational course, training room, and health advice room.

The role and objectives of digital villages are to enhance business skills and knowledge; provide Kenyans with employment; enhance provision of government services (e.g. driving licence application and police extracts); and create economic opportunities that will spur rural economic development.

Having private contractors run the digital villages has significance costs to the users. ICT Board stresses, namely, the key benefit of digital villages compared to traditional telecommunication centres is not the cost, and "digital villages therefore will not necessarily be cheaper". One reason for this is that "a digital village must be sustainable". Benefits of digital villages are rather explained in terms of providing education and learning, e-Government, and societal information, for example. 
According to the National Environmental Management Authority (NEMA) director interviewed, NEMA is the Kenyan government principal instrument in discussing ICT-initiatives across the country regarding environmental issues. NEMA is developing modules on e-learning on various aspects of the environment and offers education on environmental issues. NEMA is developing strategies and approaches that ensure women are not left behind when it comes to ICT, and therefore the director had the opportunity to be specific in what the focus government puts on women to ensure women are not left behind:

"Initially there was something they had said about women, let me just check. I think the [meeting] I had attended, they talked of giving gender a lot of focus, but there was no specific policy...They are working on that says $30 \%$ is to be women they are saying they will try and achieve that it has to be $30 \%$ if they are able to get good funding. "

NEMA's strategy is to work with female community leaders to approach women on a local level. This is because NEMA considers female community leaders as "wheels" and faces in the community, the NEMA director says. In combination with this, NEMA considers local culture and language important not to exclude any citizen.

According to the director interviewed at ICSIT, the Ministry of ICT in Kenya has found that one way of filling the lack of ICT is to set up digital villages, which "is still in what we call it's infancy age", the director says. Connectivity is a major challenge since digital villages are supposed to serve those in resource-poor environments: for example by helping promoting their business and providing literacy training. The ICSIT also got the question about gender issues and about a timeframe for completing the Digital Villages Project, and the answer was as follow:

"These are not yet on the ground but hopefully soon they will be able to put out and then we can see how they are doing...there's something the government create they call vision 2030. Of course vision 2030 is by 2030 all that will be up and live but $i$ don't know...in the next two or three years something is supposed to be in one site in Kenya. The only thing is...they went it was an ICT park identified the land then they started arguing about it when the owner realised that the government is buying the land then a lot of people started saying it's my land, I want to sell it...they are dealing with those kind of politics but we expect by 2012 at least something to start with then go from that."

\section{Observations from the Pasha Centres}

Notable differences between a digital village and a traditional telecentre or cybercafé in the Kenyan context made from observations are telecentres are more commercialised with the aim of making profits while a digital village is not commercialised to such an extent, but rather with its aim to serve the community. Telecentres have no tailored portals and special access to governmental material, which is true for digital villages. Digital villages are strategically located near rural areas or resource-poor environments, while telecentres are mostly found in urban areas. Managers of digital villages are trained while those of telecentres are not necessarily trained. Digital villages are recognised by the government and assisted where need be, while telecentres mostly are not. 
Kangundo Blossom, Eastern province, is located in Kangundo town. It is a small centre with about 14 computers but looking to expand soon to another town as it serves the two major towns. It has three employees and does more than provide the public with access to e-government services. For instance, it acts as a link to the outside world. It provides training, scanning, printing, and web-design classes, and services to the community. It trains and teaches students at the centre. In general, women or girls are not interested in the centre for the following reasons. Older women of the age bracket of 35-50 feel technology is too much for them and it is for young people. Therefore, they are not interested in the centre but send their children there. The age bracket found in the centre that had a majority of females was of 18-25 approximately. This group does not use the Pasha portal but rather use the centre for social reasons, Facebook and mail. Most women feel the centre is a "man's world" and women play a little role. Nevertheless, most females at the tertiary level of education understand what the Pasha Portal is about. The centre serves schools around, especially colleges with critical information with the use of e-books and other ICTs. Most university students throughout the area use the centre for research and assignment purposes. The centre also serves the community with information regarding the growth of crops and other labours with regard to i.e. agriculture. Kangundo Pasha Centre is the centre that links the rest of the world with the small village and is mostly used to acquire Kenya Revenue Authority PINs thus has saved a lot of business and individuals the hassle of travelling to Nairobi. The centre plays the role of disseminating information to the community in that it prints out posters with social events, activities and other information, e.g. religion events. Its most admiring role is that of teaching any person the use of email and computers at an affordable cost compared to the cost of the nearest cyber café. The major setback is lack of power especially when it rains. One of the entrepreneurs has bought a generator and is planning on buying modems as a backup plan to the Internet services provided.

Malindi Ynet International, Costal province, is located near a tourist area and is run by a female manager. The centre is placed in the town centre for all people to access the services. This is the only Pasha centre that runs from 7:30 am to $10: 30 \mathrm{pm}$, this is because it is located in a tourist destination. It is well known by the community because they have marketed themselves well over the years and have been providing quality services to the community. The owner has started teaching users IT and about computers. The owner has plans of expanding businesses to cater for these students in opening a classroom outside the centre itself. The centre has longest opening hours of all centres visited. It is the only centre that is linked with the main contributors (founders) and still uses their services. The owner and management are very keen to each individual client and their needs, e.g. they take their time to teach and serve each user. The centre is fairly organised and mannered in a very responsible way in that unlike all the other centres, the manager has constant Internet and her clientele is vast in that the manager accommodates both low and high profiled persons. The centre offers other services like scanning, photocopying, lamination, fax services and making of international calls. Employees are well acquainted with the local language for use to communicate with those who do not understand or speak Swahili/English and want to access the services. The centre enjoys a relatively steady supply of power and therefore power failures are rare. On such an occurrence, they have a generator that backs the centre. The centre is the only Pasha Centre that makes use of the portal (90\%) the most in the whole country. The centre and community to a notable extent face issues regarding health/STDs and prostitution. The centre also acts as a workstation for a radio presenter who works at radio Rahma. The centre has a fair number of women users but still faces some 
challenges when it comes to women. For instance, women are not literate so they avoid using the computers. Women who come to the centre mostly want to communicate with the tourist that they met during the high season. Most female users have not used a computer but they have heard about information technology. 80 per cent of the female users come from the rural areas to come and use the centre. Most female users come back to the centre to be assisted because the centre also offers training and education.

Meru centre, Central province, is accessible to users. It is located in Meru town. The centre offers IT services but is not the only centre providing these services. The centre is well .run and most of the services of Pasha are utilised fully. The women here are highly educated therefore know a lot about IT services and make good use of the centre. The youth are most conversant with the centre in this, which means age bracket of 15-30, but also older women are involved. The local women use the Internet service at the centre frequently. The ratio between females and males who utilise the centre would be at 50:50 respectively. The economic activity of the town is mainly farming and the Pasha information has not been fully utilised but would work wonders if fully utilized. Just like all the other centres, the use of pasha is limited to those who take keen interest in and have the logins to be able to access it. The centre plays the role of disseminating information to the community as it has posts within about the community events and it does printing for the community. Training also takes place and is mostly basic training, i.e. packages from mainly one of the biggest Software companies.

The Mukuru centre, Nairobi province, is accessible to users. It is a small, well-hidden centre with about 14 computers and several employees. The centre only provides Pasha services to the students. The centre is located in an enclosed environment. There are no other users except the students who study within the centre and persons affiliated to the centre. The centre has a manager but is owned and mostly managed by nuns. It acts as a link to the outside world for the students. The centre is located in a school for the less fortunate and therefore all the users come from the slum. A part of one male user, all of the users at time for observation was females. The users of the Pasha portal at times have no idea they are using the Pasha portal and they refer to it as the Internet. The users are not very literate and they find it hard to communicate. The centre deals with youth mostly.

The centre uses Kenya Data Networks [http://www.kdn.co.ke/] to be able to provide users Internet services and not Telkom Kenya [http://www.telkom.co.ke/] as was suggested by the ICT Board. Most of the students use the portal to study hairdressing. The age bracket of the female users is from 12-30. Females are not highly educated and most have never used a computer before. The vocational training helps the women be able to learn hairdressing from it and the women enjoy it but they cannot access the portal easily and need guidance to get to it. Most females' teachers wish the portal would provide the catering course material online as this would make their work easier. The reason is they are dealing with students with little knowledge of the use of the Internet and with little knowledge of English. Mukuru training centre is the only Pasha centre that has or does vocational training in the country now. They have the best internet connection comparing to other centres and enjoy a relatively good power supply. They train their students about IT/ICT in their area of study, e.g. hairdressing. The amount of time allocated for each student to use the computers and the Internet is an hour per week. Thus, the students do not have enough practice for their own benefit. 
The centre is donor funded, making it dependent. This is because it is not run as a commercial business like other Pasha centres. They do sell the products and services that students produce; e.g. Beadwork, table mats, clothes, hair services, to supplement the funds they get from donors to finance other small projects. Through the manager, we got a chance to view the design and contents of Pasha services. We were not able to document the user's response in terms of using the Pasha portal because none of them knew or understood the Pasha portal \& services it offers. Although some show vaguely to have an idea of certain contents like the hairdressing learning course materials.

\section{Managers perspectives}

The managers talk about nuns who manage one centre, apart from this, there is no emphasis on females neither in particular nor in general. Major emphasis is put on students in general rather than on women in particular. One of the goals of the centres is to bridge the gap between rural areas, which often are resource-poor, and urban areas. One of the managers stresses for example:

"The basic thing that has mainly driven people out of the word communication is that they are cut out of communication this is because of lack of access to information, lack of availability of this information so we bridge that gap."

According to the managers, Kangundo and Meru centres follow that of standard model whereas Makuru and Malindi follow that of advanced model. The digital villages are maintained and sustained by having an "expert" in place all the time, makings sure everything is in good working condition. However, not all Pasha Centres are open for everybody outside. One manager accentuates:

"[One of the centres is] strictly for the students here and that's because of security reasons"

The same manager continues, this is something that has been discussed at length by the management and the people in charge of Pasha. In addition, the manager means, they use Pasha for the materials like any other Pasha Centre only that it's not that commercial because this is an NGO sponsored centre and they do not work for profit; only the students who come here benefit from Pasha. To attract people to centres managers go out and market it. Nevertheless, the centre in Malindi is located near a place where tourists are staying. One of the managers of the centre believes, this is not really of any benefit, because tourists are using the facilities available in the hotel areas instead, but the centre and local people are directly influenced by the hotels cycles, though:

"I am working with those people who depend on the tourists in our centre because even if it is high season I cannot see any tourists here; they have everything in their own hotels, they have contacts, Internet, etc. But the locals working at the hotels are the ones I depend on so if the season is down that means the people will not get their daily income in the hotels. It affects me directly."

\section{Ownership}


The managers consider them jointly with the users being the community because they all live there. Local needs are considered in different ways. For instance, by doing research to highlight the customers' needs, or by putting the students needs into consideration, binding, printing, laminating their documents, and providing Internet using the Pasha portal. However, this portal is not so frequently used, a manager comments. Nevertheless, the same manager stresses:

"we try to cater for the needs of all the students without a doubt but you can't get everyone satisfied always."

Another way to consider local needs is described below.

"The centres offer lectures and the community based scripts through the Internet so that [users] won't need to go to the head office to seek donors, accessing Information on how to implement, grow up, financial development and financial gain."

"The centres also enable people to cut their expenses when acquire and access information from the Internet. The users are also supported in that they get education on modern technology."

One manager informed with regard to their centre, the programmes are supposed to be community owned:

"It's difficult for the community to own up because of the mentality. The nuns are there to help so for the community to take full ownership it's going to take quite a while for them to take ownership because to them taking ownership is to take responsibility which they are not ready to do."

Considering what the managers do in making the centres fun, motivating, and rewarding for all parties, one manager says it is "a sense of personal satisfaction when you see a girl or a boy walk in here hopeless and by the time they leave here they are smiling." Another manager starts talking about managers who are nuns.

"I think the nuns have really made this place highly up market in terms of equipment, in terms of training courses like our staff are highly trained.. all we do tailor make our syllabuses in terms of what do the students really need...because we don't even sit for any government exams apart from dressmaking."

\section{Local needs (e.g. education, literacy, job, and diversity)}

Overall, little attention is paid to language and literacy. The managers emphasise they rarely use tribal languages because users come from different language groups. Swahili is the language in use in all four centres to communicate with clients, with only few users who prefer using their tribal language. Despite this fact, to some users it seems to be important the possibility to communicate, especially informally, in a tribal language, instead of using Swahili or English, which is considered by one manager:

"First of all, I know the local language and I have to talk to them in their local language to understand what they are studying. Malindi is a Giriama town and I can speak Giriama fluently 
even the jokes, so most of them think I am a Giriama. When they come here they speak to me in Giriama and I have to respond to them because they know I am a Giriama but I am not I am a Luo."

Overall, those who already are literate and have a certain literacy skills use the centres. Nonetheless, female managers work more actively than male do to inform and reach those people who are literate, lack digital literacy, and general knowledge about what the centres have to offer:

"I help the community in teaching them about computers and Internet services. Most of them do not know anything about computers and the Internet, this is about $75 \%$ of them...I have to teach them how to use the computers."

"Like the Maasai who are security guards at the hotels, they come here but they don't know anything; how to read, and how to speak English. I have taken time with my girls[attendants] to teach them on how to use the computers so that they cannot depend on us all the time. Maybe they have private things to do but they do not know what to do. I have to teach them this one is $A$ $B C$. Maasai's tell me openly that they have never been to grade one. I don't discourage them, I give them hope that they can do it. I tell them anyone can learn using the computers even if they went to school or not but unless they have interest. I found out that they do have interest but they don't know how to use it."

Although manages agree it is important incorporating all people, they mean, one reason for not consider largely illiterate people or people who need to go back to class is, these people do not come here to use the centres.

"To be honest we have never had anyone like that. I don't know how to handle that given."

"Of late we have not had a case of somebody who cannot read the content of Pasha as such, because mostly, I am using Pasha for the students and most of them are literate in a way."

Though, the managers take account of students in general, one female manager emphasises students with special needs, e.g. who are illiterate or visually impaired, making them become an integral part of the community, thus acknowledging their existence.

"Every student that comes here is a special student...we have students with very special needs. Some of them, like now we have illiterate, completely illiterate students, we have visually impaired students. I would say we have a lot of vulnerable cases in terms of health, disabilities in terms of education and even in terms of background."

The users are able to apply for jobs through the Pasha Portal. However, not so many people know it, one manager. Therefore, they work on informing the users about this; for instance helping them retrieving and downloading job application forms for government jobs.

A major concern is how to reach the most vulnerable people. There were different strategies but all agreed upon the best way is to walk around among people. One of the most specific ways managers reach local people is by informing them in the local churches that they can come and 
use the services. Further, because of decreased costs for using services such as the Internet, more and more people can now afford using it:

"Internet was very expensive and no one could stay for an hour because it used to cost 5 shillings (0,05 EURO, 07/12/10) per minute then it went down to 3 shillings, then to 2 shillings, now it is 1 shilling. Now everybody can afford it and use it."

Not only the usage of the Internet itself is better and in a par with what the majority can afford, but this usage has lead to a decrease of other costs as well:

"If you want to check your KRA [Kenya Revenue Authority] pin number you do not have to go to their offices, you can do it online. If you want to check how far your ID is in being processed you come to Ynet international, go to the Internet and get all the information about your ID. If you want to check your returns to KRA there is no need to go there you can do it on their website."

One of the centres policies is to empower young people from the surroundings, providing education. The portal in use, called Pasha Portal is helpful in this sense. The centres can provide training, e-learning, and government documents like the Kenya Revenue Authority PIN (KRAPIN, http://www.kra.go.ke/). One of the centres is keen on vocational training because their main concern is malaria and typhoid.

"Malaria is all over. We have outbreaks, typhoid, all that so those are our biggest concern in the vocational training."

The managers agree with one another it is important to accommodate all people no matter of their prior knowledge. For instance, a tool in use to empower with literacy skills is the Pasha portal to get the technology on literacy to the community. One of the managers emphasises women in this respect.

"[Women] don't specifically come here to work on the computers but when they get here they get curious. 'What are all these machines'; they think they are TV's. 'Are you selling them?' We tell them no. 'These are machines' and they are for this, this and this. Others see the webcams and get curious; 'what are they?' Because they have light and when it is dark, it lights up. So, we tell them and in the process of explaining to them what that does and under what circumstances they use them for, they get informed about the Internet. They know that there is Internet and you don't need to travel to see a person away, you don't need them to send you pictures, so you can talk as you see them online. That's how we explain it to them."

The managers are satisfied with what the centres offer. For instance, they advertise courses from one of the biggest software company for students who come and non-students. This is what one of the managers refers to as e-learning. Another manager stresses, they log student's activities on the computer and the Internet. The manager calls this to "assess" and even with the training the students do in IT they assess. This gives the manager a chance to evaluate the student's current skills individually and follow the student up when they have finished their course. 


\section{Users experiences}

\section{Ownership}

The users find the services good though male users have considerations about females and ICT. One male user comments that women are "scared for machinery". Two other male users state the following with regard to ICT usage and female owners.

"Women don't do such."

"Women don't know anything about computers, they fear it. For example, if you switch off the monitor and tell her that she has spoiled it she would believe it as in they just don't know."

The female users are not that specific in their answer on female owners, cannot tell whether female owner should be different compared to males.

"I have never seen one run by a female but I would like to be the first one if you guys promote me, 'cos, I am sure this research is for something."

"Men, am telling you, my dear. Men when it comes to IT, men think that women can't handle the technical stuff. Just like when I went for my attachment, most of the people there prefer male technicians. To me, yet am far much better because they used to come and ask me about stuff that they were called to go solve you know in computers for the big boss. Well, shame, but that is what I think."

\section{Local needs (e.g. education, literacy, job, and diversity)}

All users agree, the centres fill an important function to them and to the people outside the cities. They also agree with it should be more centres so as it becomes cheaper to use them, and provide faster Internet, and give students special rates.

When it comes to advantages for female users, all females say they can speak to their friends who are close or far away, and they can access services such as printers. By observing, it is notable that social networking sites are of major interest among users. Two female users state they use the centre to browse especially on social networking cites, to send email to friends, and meet people. Overall, the users believe the services are well and the attendants are good and welcoming. The users employ e-government services such as KRA-PIN and do not have any particular complaints about the centres:

"I have a love for IT. The computers are a fancy thing, the machines are data connected to interact. I like it. I would be disappointed, truly, if the place shut down."

"I would not call this place rural that much as it is only 2 hours from the big city but they save us money to go to big towns to be able to access Internet can you image if they were not here."

Although the users are satisfied with the services, they think the connection could be even better. Here is a comment from a male: 
“...saying that they are excellent may also be overstating because I think initially we had a higher speed connection, now it has slowed down a bit, but it is still ok. Normally I usually take 20-30 minutes that's around 30 Kenyan shillings. I don't think I have a problem with that considering the connection is ok...The centre is reliable in terms of services offered."

The use of language has not been a barrier as such, i.e., most users know Swahili. The Pasha portal has not put the language aspect in place but is working on it. The reason found to this is, users without any proper command in English or Swahili do not come to the centres. Therefore, any kind of language policy has not been a factor for users.

Although, the majority of the users knew about ICT before, one user says she does not know what a digital village or a Pasha Centre is. Nevertheless, she thinks ICT is good but "just not ready embraced by everyone." Another inexperienced user expresses she was not able to use ICT before, but the centre has assisted and has learned "a lot in this place". Female users believe the centres have the potential to empower women. In general, the users find no barriers in regards to the usage. In general, female users also think women who come to the centres are literate and women and computer is a good combination. The following are quotations from four female users:

"Digital villages gives women a voice to talk 'cos I would like to do political science and on the net you can say what you feel without any fear given the fact of what happened in 2007."

"Women knowledge is power and they help us look for jobs from the comfort of our home area and besides they provide just the same benefits a man get they are no special advantages as such"

"I think [the centre] helps women a lot because they come here to search for jobs."

"I think IT is awesome with it I can do so many things as you will know that books can be an issue but Internet helps a lot."

"IT is the only way forward for us [women and girls] I think the only way forward look at elearning it is just what we need."

Other advantages with the centre are, especially for those in the villages, the possibility to maintain the city lifestyle when coming home from studies in the city.

"I would say Internet does a lot for the people in the village, because if you study in the city and come home you can still continue with the same lifestyle, e.g. you can still check your mails and still access the Internet but it is not so stable."

Overall, the centres are largely used for two things; social networking and education purposes, as this male student comments:

"We had an assignment. I just googled the work and downloaded a pdf." 
What was not discussed, but nonetheless observed, was the issue of prostitution that affect the centres and the environments largely. The locally access to Pasha Centres and digital content to a certain extent facilitates such initiatives among users.

\section{Discussion and conclusions}

Overall, a majority of users are between 18 and 25. Most users are university students, most of which are in the IT field. Both men and women use Pasha Centres but men are in majority. Since there is no free of charge to use the Pasha Centres and such a large percentage are students, users of Pasha Centres must have a certain ability to pay and be proficient in English. Users are mainly from families with financial margins. There are several reasons for payable fees to use the centres. ICT Board believes the Pasha Centres must be sustainable, and therefore there is no question of giving away services free of charge. Further, lack of full range of software in Swahili or local languages may scare away potential users who would otherwise see an opportunity to start using the centres. Managers are not accustomed to users with a diverse background in terms of language and in need of special education, which shuts out a large group of users. The visited Pasha Centres are located in suburban and rural areas, and outside tourist centres, i.e., vulnerable areas .However, they are not located in "inaccessible" areas, so there still is a risk that the people who live mostly in isolation, after all not have access to ICT services.

Studies are arguably the most important application of Pasha Centres; from teaching to retrieve information on the Internet. It is also one of the basic ideas behind the centres; to provide learning and training. However, there is no specific training provided towards women that focuses on technical and management programme. Another important service is referred to eGovernment, which also is one of the basic ideas with Pasha Centres. However, users do not employ this service to a large degree. Instead, several users preferred services for email and social networking sites.

On a national level, the government strives to include better women in all sectors to create an equal society nonetheless, not much of this is done on regional or local levels. Instead, male managers and users mainly have a negative view on women and female users. However, there are exceptions; for instance, there are female managers, which could serve as a way of empowering women, showing them it is possible for them too.

The Kenyan Government's Digital Villages Project has potential impact to address specifically the needs of women in underserviced community as an alternative to traditional centres for communication in Kenya for all citizens. The digital villages are located in not only resourcepoor environments but also outside cities and tourist centres. Several users, especially students comment about the location that they found suitable to them as they now can access telecommunication and gain from education near their home. Education has been proved important to enhance a nation's economical growth and to be given access to education is important in terms of identity.

The digital villages also provide some form of employment, which will reduce the level of poverty in the villages. The people in the villages are being employed in the Pasha centres for example assistants, trainers and cleaners, etc. Hence, while the centres have payable fees, which may exclude the poorest, it would be difficult to employ people without those fees. 
Another potential effect as more people get employed or study, thus is reduction of crime rate and bad morals in the villages; this is because the idle youth and women will have something that can keep them busy without incurring any high costs. This will in turn make the people more knowledgeable hence empower them. For instance, through the usages of the centres, women can be able to access valuable information through the digital village that will help in running or start up their business.

The Pasha Centres have also been a link to the world from the village as many users are able to communicate with the children who go to study abroad. This makes them stay in contact without costs for travelling and post office, which would be more expensive.

The DVP has also helped bringing the government to the people who need it most as they are able to perform tasks before eventually visiting the government offices.

The Kenyan government through their platforms (e.g. NEMA and ICT Board) strives to bridge the gap between urban and rural communities. Rural communities are normally less serviced. The government needs a strategy for them not to only reach educated and literate people in resourcepoor environments; for instance, to reach people who want to become educated or gain literacy skills but do not want to or has the possibility to move to cities. A disadvantage in this respect is, no policy in regards to costs seem to be at stake, which may exclude those who are poorest from usages.

When it comes to ICT as a men's word it would be fruitful if the Kenyan government would educate the people and managers about the importance and use of ICTs as a tool for everyone regardless of demographical background. This because it is a challenge to involve poor women especially from resource-poor environments using ICT services for example digital villages (Roman \& Colle, 2002).

There are needs for the Kenyan government to consider the literacy and language issues discussed when setting up digital villages. This will ensure that all citizens feel included and accept the use of digital villages. One suggestion is to consider the introduction of both primary and continuing learning at the digital villages so as not only university students can gain, but also those who never attended school or dropped out of it. Hence, the DVP would have the potential to meet the needs of formal learning, nonformal, and informal, i.e. learning outside a formal or recognised learning institution, or with a recognised curriculum. Such a strategy would empower women in villages and help the Kenya government achieve the Vision 2030.

\section{Limitations of the study}

According to NEMA, the Kenyan government's digital villages are in initial stages of development. However, the digital villages visited were all operational.

\section{References}

Abbott, J. \& Yoong, P. (2005). The stages of telecentre development: the case of the Kapiti Telecentre. Technovation, 25(4), 421-431. 
Baker, M. (2006). Contextualization in translator- and interpreter-mediated events. Journal of Pragmatics, 38, 321-337.

Benjamin, P. (2000). Does 'Telecentre' mean the centre is far away? Telecentre development in South Africa and around the world. The Southern African Journal of Information and Communication, 1(1), 2001.

Bernard, H.R. ed. (2000). Handbook of methods in cultural anthropology. Walnut Creek: AltaMira Press.

Brammer, J. (2006). A phenomenographic study of registered nurses' understanding of their role in student learning - An Australian perspective. International Journal of Nursing Studies, 43, 963-973.

Crellin, I. (1994). The Australian Telecentre Program: A New Approach to Technology Transfer and Rural Community Development. Paper presented at the International Conference of Agricultural Economists (22nd, Harare, Zimbabwe, August 22-29, 1994), 1-14. Retrieved from ERIC database.

Dey, I. (1993). Qualitative data analysis: a user-friendly guide for social scientists. London: Routledge.

Dlodlo, N. (2009). Access to ICT education for girls and women in rural South Africa: a case study. Technology in Society. Vol. 31(2), pp 1-12.

ebrary, Inc. (2003). Lifelong learning in the global knowledge economy [Elektronisk resurs] challenges for developing countries. Washington, DC: World Bank.

European Commission (2007). Waht is lifelong learning. The view from the European Commission. Headquarters, p 22-23.: http://www.esae.org/articles/2007_08_005.pdf.

Fontelles, J.B. \& Enestam, J-E. (2006). Recommendation of the European Parliment and of the Council of 18 December 2006 on key competences for lifelong learning. Official Journal of the European Union, L 394/10.

Gaiani, S., Hansson, H., Meegammana, N., Mozelius, P. (2009). Critical issues for e-learning telecentres in Sri Lanka and India. ICDE World Conference on Open Learning and Distance Education, Maastricht, Netherlands, M-2009.

Gómez Díaz, M., \& Sandoval-Almazán, R. (2009). Tecnologías de la información y aprendizaje organizacional en telecentros. Revista Eletrônica De Sistemas De Informação. Accessed 06/27/2010: http://revistas.facecla.com.br/index.php/reinfo/article/view/356/450.

Hansson, H., Mozelius, P., Gaiani, S., \& Meegammana, N. (2010). Women Empowerment in Rural Areas through the Usage of Telecentres - A Sri Lankan Case Study. 2010 International Conference on Advances in ICT for Emerging Regions (ICTer), 5-10.

Huyer, S. (2003). Gender, ICT, and Education. In World Bank, Engendering ICT, Chapter 5, 100125).

Jensen, M. and Esterhuysen, A. (2001). The Community Telecentre Cookbook for Africa. Recipes for Self-sustainability, How to Establish a Multi-purpose Community Telecentre in Africa. United Nations Educational Scientific and Cultural Organization Paris, 2001. 
Kenya ICT Board (2010) About Kenya ICT Board. Accessed 26/06/2010 from http://www.ict.go.ke/index.php/theboard.

Kenya ICT Board (2010b) About PASHA. Accessed 11/11/2010 from http://www.ict.go.ke/index.php/.

Larson, R., \& Murray, M. (2008). Distance Learning as a Tool for Poverty Reduction and Economic Development: A Focus on China and Mexico. Journal of Science Education and Technology, 17(2), 175-196. Retrieved from ERIC database.

Ndeta, P. (2003) ICT Integration Social and Economic Development: Kenya's Perspective. In: Marshall, S., Taylor, W. \& Yu, X.H. (ed.) (2003). Closing the digital divide: transforming regional economies and communities with information technology. Westport, Conn.: Praeger.

Oyedemi, T. (2003). Universal access wheel: Towards Achieving Universal Access to ICT in Africa. The Southern African Journal of Information and Communication, 5, 90-107.

Paulk, M.C., Curtis, B., Chrissis, M.B. and Weber, C.V. (1993). Capability maturity modelsm for software, version 1.1. Technical Report CMU/SEI-93-TR-024 ESC-TR-93-177, Software Engineering Institute Carnegie Mellon University Pittsburgh, Pennsylvania, Pennsylvania, February 1993.

Project Africa. (2010) Empowering Women and Girls in Rural Africa. Accessed 07/12/10: http://www.projectforafrica.org/.

Ramos, A., Nangit, G., Ranga, A., \& Trinona, J. (2007). ICT-Enabled Distance Education in Community Development in the Philippines. Distance Education, 28(2), 213-229. Retrieved from ERIC database.

Rogers, E.M. \& Shukla, P. (2001). The Role of Telecenters in Development Communication and the Digital Divide. Journal of Development Communication: Special Issue on Telecenters, 12(2), $1-6$.

Roman, R. \& Colle, R. 2002, creating a participatory telecentre enterprise. Creating a Participatory Telecenter Enterprise. Paper prepared for the Participatory Communication Research Section in the annual meeting of International Association for Media and Communication Research, Barcelona, July 21-26, 2002. URL: http://ip.cals.cornell.edu/commdev/documents/ictpaper-barcelona.doc.

Terry, A. \& Gomez, R. (2010). Gender and public access computing: An international perspective. The Electronic Journal of Information Systems in Developing Countries, 43(5), 1-17.

UNESCO (2009) Annual Report 2009. 2010 UNESCO Institute for Lifelong Learning. www.unesco.org/uil. 